\title{
DISCUSSION QUESTIONS ABOUT THE ROLE OF A LECTURE IN THE PROCESS OF TEACHING THE DISCIPLINE "PROPAEDEUTICS OF PEDIATRICS" IN THE CONTEXT OF MODERN MEDICAL EDUCATION
}

\author{
N. Mishina, S. Ilchenko, A. Fialkovska
}

\begin{abstract}
Важливою задачею сучасної вищої школи Украӥни є всебічне вдосконалення навчального процесу на основі кращих досягнень світової та вітчизняної дидактики. Серед великого переліку форм і методів навчання у закладі вищої освіти лекція завжди посідала чільне місие. Проте на сьогоднішній день в умовах реформування вищої освіти питання про доцільність лекції, як невід 'смної частини навчального процесу, активно дискутується. Метою дослідження було визначення значимості і роль лекиії в процесі викладання дисиипліни «Пропедевтика педіатрії» в умовах сучасної медичної освіти. Проведено анонімне анкетування 593 студентів третього курсу Дніпропетровської медичної академії, серед яких: 377 респондентів - вітчизняні студенти, 170 - іноземні англомовні студенти та 46 - іноземні російськомовні студенти. Як показали результати, для більшості вітчизняних та іноземних студентів третього курсу лекиія є обов'язковою формою навчання, а лекиії з «Пропедевтики педіатрії» є досить інформативними та необхідними. Крім того, студенти досить високо оцінили роботу професорсько-викладацького колективу з розробки лекцій та рівень подачі лекційного матеріалу на кафедрі пропедевтики дитячих хвороб. Найчастішими пропозичіями як вітчизняних, так й іноземних студентів, шзодо підвищення ефективності лекцій виявилися: збільшити кількості лекцій та навчальної інформації в них; наводити більшу кількість клінічних прикладів з власного досвіду практичного лікаря; збільшити кількість відеоматеріалів під час лекційного заняття. Отже, лекція в сучасних умовах вітчизняної вищої медичної освіти повинна залишатися провідною та необхідною формою організації навчального процесу. Для підвищення ефективності лекційного матеріалу викладачам необхідно враховувати індивідуальні особливості та потреби студентів
\end{abstract}

Ключові слова: лекиія, анонімне анкетування, студенти, медична освіта, навчальний процес, пропедевтика педіатріi This is an open access article under the CC BY license (http://creativecommons.org/licenses/by/4.0).

\section{Introduction}

Higher medical education undergoes today deep crucial changes, aimed at solving a strategic task - to inherit development tendencies of the European higher school, to make the content and forms of education correspond to the further integration into the European and world educational space [1]. Traditional methods, taken place in the educational system of Ukraine till now, cannot fully meet the requirements of modern hightechnological branches of many foreign countries [2]. So, the development of higher medical education in Ukraine under reformation conditions provides a series of changes, related to the learning process and teaching methods in a higher educational institution.

One of the most important components of the educational process at higher educational institutions is forms of its organization. According to the Law of Ukraine "On higher education", main teaching forms at a medical university are lectures, practical activity and students' independent work [3].

Propaedeutics of pediatrics is one of first clinical disciplines that gives students a base knowledge level for studying further profile pediatric disciplines and forms clinical thinking in future physicians [4]. So, for providing a structured approach in studying propaedeutics of pediatrics, from our point of view, it is necessary to combine all learning forms - lectures, practical activities and students' independent work. But in new standards volumes of lecture hours decreased almost by a degree, and students' independent work becomes to occupy the first place that, according to specialists, provides formation of deep knowledge in them, independent creative thinking and improvement of earlier formed professional abilities and skills [5]. Under such conditions there forms an impression that a role of a lecture course in the educational process is secondary and little effective. At that modern students have a wide access to scientific-learning information on paper (textbooks, atlases, periodicals, monographs) and e-mediums (e-textbooks, internet, video- and audio-lectures and so on), and it is not interesting for them to listen and to summarize traditional lectures that may be read in a textbook or internet. At the same time the wide volume of scientific information that increases continuously and the absence of living communication with a teacher doesn't always allow students to separate the main material of a discipline for further clinical thinking in the information flow [6]. So, it needs studying the attitude of students themselves to a lecture as a form of the educational process. 


\section{Literary review}

A lecture in a higher educational institution always occupied a leading place among the wide list of learning forms and methods, historically constructed and probated during the long time. Considering its role and pace in the educational process, it must be acknowledged, that from the moment of higher education generation it has been a key form of study. A lecture organically combined in a single whole a certain volume of knowledge, in such a way providing formation of academic disciplines [7, 8]. But times changed, and for today the question about the expedience of a lecture as an inalienable part of the educational process is actively discussed. Adherents of traditional didactics accent its advantages. In a series of cases a lecture functions as a main source of information, for example, if information is absent in handbooks and textbooks, or when separate sections and themes are too complicated for independent study. In such cases only a lector can methodically help students in mastering a complicated material $[7,9]$. At the same time their opponents state that a lecture as an auditory form of communication with students is least effective among other studying forms at higher school. At a lecture the activity of information perception by students decreases - it forces a studying person remain an object of the pedagogical process, and synchronous communication with a rather big audience limits the teacher's possibility to realize a differentiated approach and to make a lecture equally interesting and useful for both excellent students and weaker ones [9, 10].

But the world experience demonstrates that rejection of lectures decreases a scientific level of students' training, brakes the system and evenness of the work during a semester. And the abovementioned defects may be mainly overcome by a correct method and rational construction of material presentation [10].

A modern lecture in a higher educational institution is not only a means of giving scientific and learning information, but a process of strengthening a learning motivation, intensification of rational activity, organization of students' independent work, impulse to continuous renovation and improvement of an acquired experience [11]. So, the process of professional training of a competent physician in the epoch of globalization needs creation of correspondent conditions at higher medical educational institutions, especially in renovation of the content of teachers' activity, which integrates professional, scientific and pedagogical components. The effectiveness of the educational process and its result mainly depend on taking into account evolutionary personal transformations of representatives of the modern generation of future specialists [12]. In 1991 N. Howe and W. Strauss created a so-called "generation theory", according to which, they replace one another each $20-25$ years. The representative of the Harvard Medical School (USA) D. Roberts added it with an interpretation that such generations create groups of persons of a same age, similar experience and environment, connected by common values, ideas, lifestyle and challenges. According to this theory, "traditionalists" ("veterans"), born in 1922-1945; "babyboomers", appeared in 1946-1964; "X-generation", grown in 1965-1980 were replaced in 1981-1999 by "millennials" ("Y generation"), and at the beginning of XXI - by "centennials" ("Z generation"»), for whom the information space widened essentially and became accessible due to the internet, devices, elimination of boundaries between states that favor a possibility to cognize the world [13].

"Millennials" is a generation, formed, when the "Internet" caused the global transformation in traditional mass media. They find knowledge mainly on internetresources, not in books. This is a generation of freethinkers and a possibility of self-expression is extremely important for them $[14,15]$.

"Centennials" is a generation, for which a teacher stopped to be a main source of knowledge, because they can instantly get modern information from any part of the world. The main problem of " $Z$ generation" is that they are not accustomed to offline learning methods from the past and don't find it necessary to memorize information. They are striving for interactivity, concretely set educational aims and practical professional directionality [16].

Such generation change resulted in the effectiveness decrease of old learning approaches. In this connection actual requirements as to acknowledgement and taking into account of peculiarities, life principles and inclinations of "millennials" and "centennials", formation of individual and maybe unique learning style for getting results appear [13].

Inclinations of modern medical students are the orientation on practical aspects, interactivity with using modern technologies, learning by the method of "trials and mistakes", involvement of game elements to the learning process. Instead of big textbooks and long lectures - brief key information - because attention to a book is lost fast. Communication is also of great importance at working in a group; close contact and "guaranteed sympathy" of teachers - similar to parental one. The auditory learning, including lectures, must be used not for retelling facts from "Google", but for acquiring a competence of their use for solving concrete problems [17]. It dictates a need in renovation of learning programs and implementation of interactive, more flexible approaches to study. A routine practice may be also continuous "feedback" from students as an anonymous questionnaire as to perception of a lecture, practical activity, learning course as a whole.

So, the task of a modern teacher is not only to adapt to new requirements of the educational environment, but also to act for advance that needs an interactive approach at giving a learning material, using modern technologies and innovative didactic approaches.

\section{Aim and tasks of the research}

The aim of this study is to determine a significance and role of a lecture in the process of teaching of the discipline "Propaedeutics of pediatrics" under conditions of modern medical education.

To achieve the aim, the following tasks were set:

1. To determine third-year students' attitude to a lecture as a form of the educational process.

2. To highlight a students' idea as to increasing the effectiveness of lectures at teaching "Propaedeutics of pediatrics. 


\section{Materials and methods}

The research was conducted at the department of pediatric diseases propaedeutics of the State institution "Dnipropetrovsk medical academy of the Ministry of Health of Ukraine". The discipline "Propaedeutics of pediatrics" consists of 150 hours, of which 30 hours are given for the lecture course. Topics of the lecture course discover problem questions of correspondent sections of pediatrics propaedeutics. At lecture activities the program material is given by multimedia presentations, in which information is presented not only as a text, but by such means as photos, animated pictures, audio-texts, digital video. It must be noted, that at the last review and approval of the lecture course at the department, there were analyzed its quality and correspondence to main principles of effectiveness increase, namely: distinct structurization of the material with brief intermediate conclusions, laconic final messages, no more than 3 , bright clinical cases, systematic use of means of keeping attention by activation the audience no less often than each 15 minutes, by using interactivity - open questions or tasks for choosing one of offered variants of answers. At the same time the attention was paid to the quality of the prepared multimedia presentation and delivery of a lecture by a teacher.

At the end of the lecture course there was conducted the anonymous questionnaire of students for evaluating the lecture material quality and also students' attitude to lectures of the discipline. Using it, there were interrogated 593 third-year students of the Dnipro medical academy, among which:
377 respondents - native students, 170 - foreign English-speaking students,

46 - foreign Russian-speaking ones.

According to questionnaire conditions, students were offered to answer two questions as to the necessity and importance of a lecture at studying "Propaedeutics of pediatrics" and also to evaluate its quality and one of lectures by the five-point scale (including interaction between the lecturer and the audience, presence of clinical cases, audiovizualization, complication of understanding the material in whole).

The comparative analysis by groups with constructing diagrams by selected categories and descriptive methods were used at the research.

\section{Research results and their discussion}

At analyzing the first question of the form that contained the following statement: "Lectures are interesting, informative and necessary for mastering the discipline", the following results were obtained: $90.7 \%$ of native students find lectures necessary and informative, but $9.3 \%$ of respondents think that they are not necessary, obligatory learning form at mastering "Propaedeutics of pediatrics" (Fig. 1).

As to foreign students, $85.3 \%$ of Englishspeaking students and $97.8 \%$ of Russian-speaking ones consider a lecture as a necessary learning form; $14.7 \%$ of English-speaking and $2.2 \%$ of Russian-speaking students answered that a lecture is not a necessary learning form.

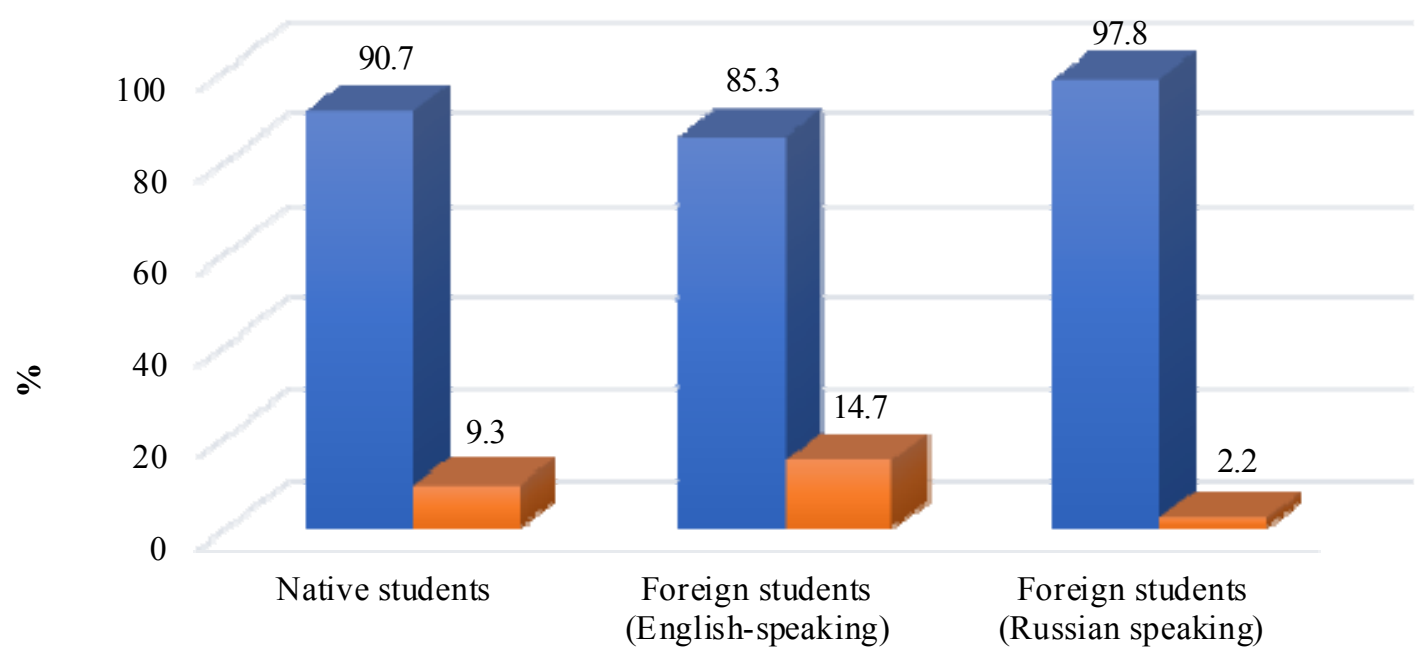

- Lectures are interesting, informative and necessary

- Lectures are not interesting, informative and necessary

Fig. 1. Attitude of third-year students to the informativeness and necessity of lectures at mastering "Propaedeutics of pediatrics"

The second question of the form contained the statement: "It is not necessary to listen lectures, it is enough to read them in free access" $60.5 \%$ of native students expressed an idea about the necessity of lectures, but $39.5 \%$ of students agreed that it is enough to read lectures in free access. From their point of view, a classic lecture is not considered today as a way of getting information, because of great possibilities of the Internet, but one of getting unique or most fresh information or generalized picture from an expert in the branch. A share 
of modern students thinks that it is not rational and useful for them to make an abstract of a lecture. Such students' attitude to lectures shocks the generation of post-Soviet teachers, but is popular among modern Ukrainian students, not depending on their success. Among foreign students, $29.4 \%$ of English-speaking and $10.9 \%$ of Russian-speaking ones said "yes" for non-necessity of lectures and their free access (Fig. 2).
Their necessity was indicated by $70.6 \%$ of Englishspeaking and $89.1 \%$ of Russian-speaking students - foreigners. At the last questionnaire stage third-year students were offered to evaluate the quality of "Propaedeutics of pediatrics" teaching and a lecturer in whole by the fivepoint scale. Among native students, $70.3 \%$ evaluated the quality of lectures as "5 points", "4 points" - $24.4 \%$, "3 points" - $5.3 \%$ (Fig. 3 ).

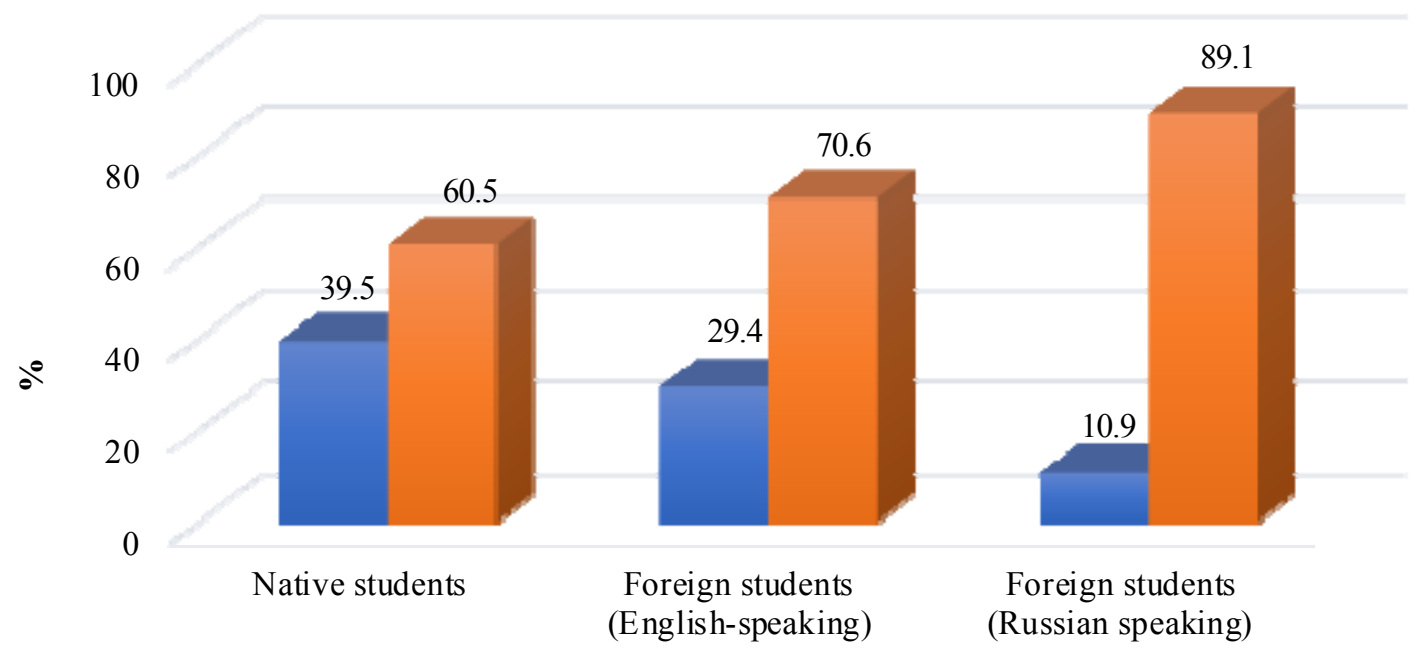

It is not necessary to listen for lectures, it is enough to read them in free access

Lectures are a compulsory learning form

Fig. 2. Attitude of third-year students to the necessity of lectures. Answers to question No.2: "It is not necessary to listen for lectures, it is enough to read them in free access" are presented

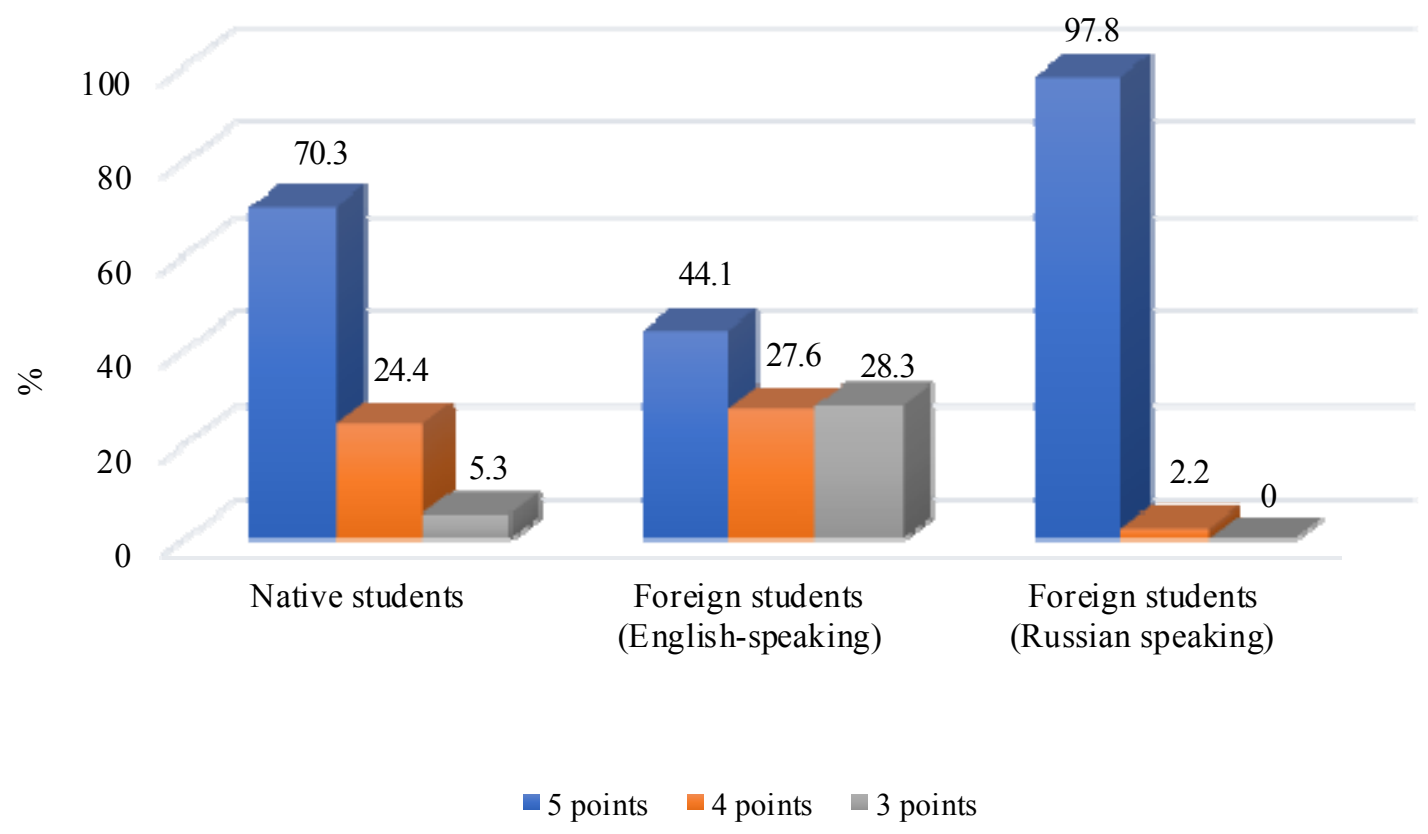

Fig. 3. Distribution of third-year students by the evaluation of the teaching quality of "Propaedeutics of pediatrics" and a lecturer in whole 
Russian-speaking students-foreigners evaluated lectors of the department of pediatric diseases propaedeutics rather high, namely: "5 points" - $97.8 \%$, "4 points" $2.2 \%$ of students. English-speaking students - foreigners evaluated the quality of lectures and a lector in whole as following: "5 points" - $44.1 \%$, "4 points" - $27.6 \%$, "3 points" $-28.3 \%$.

It is necessary to note that within the third question of the form students were offered to give their comments as to further conduction of lecture activities at the department of pediatric diseases propaedeutics. Among wishes of both native and foreign students as to conducting lectures, the main were: to increase the number of lectures and the amount of learning information in them; to give more clinical examples from own experience of a practicing physician; to use elements of "living" conversation - dialog teacher-student"; to increase the number of video-materials at a lecture activity.

Thus, at analyzing the data of the questionnaire of third-year students we have confirmed an idea that under modern conditions of native higher medical education a lecture remains a leading and necessary learning form. At that wide possibilities of IT-technologies give an ability to enrich traditional lectures with interactivity and clinical cases, to provide individualization of material presentation according to the speed of step-by-step solution of tasks by students. It is probably, most valuable in a clinical lecture, especially at first years of native medical HEIs - a possibility to motivate students to further studying and to give them explanations of situations, difficult for comprehension, and for students - to hear ideas of professional physicians, to get answers to appeared questions. Taking into account the expressed students' ideas as to the informativeness and necessity of a lecture as a learning form, and also taking into account the points, given at evaluating lectors by students, we can make a conclusion that third-year students evaluates the work of the teaching staff for elaborating lectures and the level of lecture materials presentation at the department of pediatric diseases propaedeutics rather high.

The prospect of further researches is in studying the influence of lectors' individual peculiarities on a student audience and also in explaining other methods of intensification of students' learning-cognitive activity at a lecture.

\section{Conclusions}

1. Under modern conditions of native higher medical education a lecture remains a leading and necessary form educational process organization for students of higher medical institutions.

2. The most valuable in a clinical lecture, especially at first years of native medical HEIs is a possibility to motivate students to further studying and to give them explanations of conceptions, difficult for comprehension, and for students - to hear ideas of professional physicians, to get answers to appeared questions.

3. For raising the effectiveness of lecture materials, teachers must take into account individual peculiarities, needs of students and differences of the generation continuum.

\section{References}

1. Vlasenko O. V., Drachuk O. P. Pidhotovka kadriv na tretomu rivni vyshchoi osvity v suchasnykh umovakh yii reformuvannia // Pidhotovka medychnykh kadriv u suchasnykh umovakh reformy systemy okhorony zdorovia Ukrainy: proceding. Vinnytsia, 2017. P. 33-35.

2. Romanyuk L., Kravets N. A structured approach to the teaching of microbiology, virology and immunology for medical students // ScienceRise: Pedagogical Education. 2018. Issue 6 (26). P. 30-33. doi: http://doi.org/10.15587/2519-4984.2018.140910

3. On Higher Education (with changes and additions): Law of Ukraine No. 1556-VII. 01.07.2014. URL: https://zakon.rada.gov.ua/laws/show/1556-18?lang=en

4. Analysis of the level of knowledge of pediatric propaedeutics, taught in junior courses among young doctors / Ilchenko S., Yaroshevskaya T., Skryabina E., Kramarenko N. // ScienceRise: Pedagogical Education. 2018. Issue 7 (27). P. 28-32. doi: http://doi.org/10.15587/2519-4984.2018.153376

5. Zamorskyi I. I., Khmara T. V. Znachennia lektsii yak vahomoho piznavalno-vykhovuiuchoho faktora u pidhotovtsi maibutnoho medychnoho pratsivnyka // Medychna osvita. 2016. Issue 1. P. 70-73.

6. Zhurakivska O. Ya. Rol lektsii pry vykladanni teoretychnykh dystsyplin v systemi bolonskoi osvity // Svit medytsyny ta biolohii. 2015. Issue 1 (48). P. 199-200.

7. Filippova L. V. Problemy chytannia lektsiinoho materialu u vyshchykh navchalnykh medychnykh zakladakh // Pedahohichna osvita: teoriia i praktyka. 2011. Issue 7. P. 103-107.

8. Kyryan T. I. The development of lecture form in educational process in the higher medical education of Ukraine (the end of the XX - the beginning of the XXI century) // Scientific journal of M .P. Dragomanov National Pedagogical University. 2018. Issue 62. P. 89-92.

9. Machynska N. I., Stelmakh S. S. Suchasni formy orhanizatsii navchalnoho protsesu u vyshchii shkoli: handbook. Lviv: Lvivskyi derzhavnyi universytet vnutrishnikh sprav, 2012. $180 \mathrm{p}$.

10. Modern methods of teaching of medical disciplines in higher education / Hai L. A., Sukhin Yu. V., Wenher V. F., Muksen Saied, Serdyuk V. V. // Medychna osvita. 2016. Issue 1. P. 15-18.

11. Kaidalova L. H. Teoretyko-metodychni aspekty vykladannia lektsii u vyshchomu navchalnomu zakladi // Novi tekhnolohii navchannia. 2012. Issue 72. P. 96-100.

12. Kulbashna Y., Tkachuk E., Zakharova V. New tasks and functions of the teacher of innovative type in the preparation of the competent doctor // Educological Discourse. 2018. Issue 1-2 (20-21), 141-157. doi: http://doi.org/10.28925/2312-5829.2018.12.31220

13. Tolochko S. V. Modernization of methodological teachers competence in the system of postgraduate education for the future // Visnyk Natsionalnoho universytetu "Chernihivskyi kolehium" im. T.H. Shevchenka. 2018. Issue 151 (2). P. $73-78$.

14. Roberts D. H., Newman L. R., Schwartzstein R. M. Twelve tips for facilitating Millennials' learning // Medical Teacher. 2012. Vol. 34, Issue 4. P. 274-278. doi: http://doi.org/10.3109/0142159x.2011.613498 
15. Joyner B. D. How to Effectively Teach Millennials: Understanding Intergenerational Factors // Handbook of Clinical Teaching. 2016. P. 39-48. doi: http://doi.org/10.1007/978-3-319-33193-5_5

16. Changing the format of lecture classes for new generation medical students / Iaremenko O. B., Fedkov D. L., Dobrianskyi D. V., Dudka P. F., Ilnytskyi R. I., Tarchenko I. P., Meliksetyan A. V. // Medical Education. 2018. Vol. 4. P. 117-120. doi: http://doi.org/10.11603/me.2414-5998.2018.4.8850

17. Amosova K. M. Khto taki "milenialy", i yak navchaty takykh studentiv. 2018. URL: https://ife.pravda.com.ua/columns/2018/01/16/228473/ (Last accessed: 10.04.2020)

Received date 28.01.2020

Accepted date 17.02.2020

Published date 25.05.2020

Naira Mishina, PhD, Associate Professor, Department of Propedeutics of Pediatric Diseases, State Institution "Dnipropetrovsk Medical Academy of the Ministry of Health of Ukraine", V. Vernadskogo str., 9, Dnipro, Ukraine, 49044

E-mail: nairavmishina@gmail.com

Svitlana Ilchenko, MD, Professor, Department of Propedeutics of Pediatric Diseases, State Institution "Dnipropetrovsk Medical Academy of the Ministry of Health of Ukraine", V. Vernadskogo str., 9, Dnipro, Ukraine, 49044

E-mail: ilchensv@gmail.com

Fialkovska Anastasiia, PhD, Associate Professor, Department of Propedeutics of Pediatric Diseases, State Institution "Dnipropetrovsk Medical Academy of the Ministry of Health of Ukraine", V. Vernadskogo str., 9, Dnipro, Ukraine, 49044

E-mail: fialkovskaja.a@gmail.com 